\title{
Effect of Baluran Gum Arabic on Blood Glucose Level in Diabetic Rat (Rattus Novergicus)
}

\author{
(Efek Gum Arabik Baluran terhadap Kadar Gula Darah Tikus (Rattus Novergicus)) \\ Hidayat Teguh Wiyono*), Eva Tyas Utami, Dinna Wahyu Putri Wardhani \\ Jurusan Biologi, Fakultas Matematika dan Ilmu Pengetahuan Alam, Universitas Jember
}

Jalan Kalimantan 37, Jember 68121

\section{ABSTRACT}

Diabetes mellitus is a metabolic disease which indicated with increasing blood glucose level. Carbohidrate, protein, mineral and secondary metabolite (alkaloid, tannin and saponin) can be benefical to treat diabetes mellitus. Rats were randomly divided into three groups. First, control group. Second, STZ group, untreated diabetic. Third, STZ+GA 15\% group, diabetic treated with GA 15\%. Result showed that blood glucose level

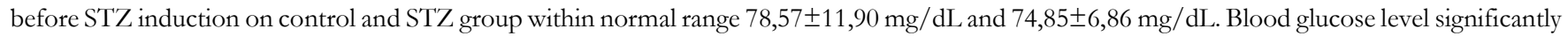
increase after STZ induction on STZ and STZ+GA 15\% group become 375 $\pm 6,53 \mathrm{mg} / \mathrm{dL}$ and 346,42 $\pm 50,23 \mathrm{mg} / \mathrm{dL}$. Diabetic rat treated with GA $15 \%$ revealed decrease in blood glucose level compared to untreated diabetic rat. Blood glucose level on STZ+GA $15 \%$ group continuously decrease become $96,42 \pm 13,45 \mathrm{mg} / \mathrm{dL}$ and $82,14 \pm 9,19 \mathrm{mg} / \mathrm{dL}$. In conclusion, GA 15\% could reduce blood glucose level on diabetic rat.

Diabetes mellitus merupakan penyakit metabolic yang ditandai dengan peningkatan kadar glukosa darah. Karbohidrat, protein, dan metabolit sekunder (alkaloid, tannin, dan saponin) dapat bermanfaat pada pengobatan diabetes mellitus. Pada penelitian ini tikus dibagi menjadi tiag kelompok yaitu kelompok control, kelompok diabetes (dengan perlakuan STZ) tanpa perlakuan gum arabik, dan kelompok ketiga yaitu kelompok tikus diabetes (dengan perlakuan STZ) dan Gum Arabic (GA) 15\%. Hasil penelitian menunjukkan bahwa kadar glukosa darah sebelum induksi STZ

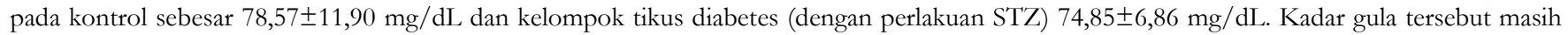
dalam kisaran normal. Setelah induksi STZ terjadi peningkatan kadar glukosa yang signifikan yaitu 375 $\pm 6,53 \mathrm{mg} / \mathrm{dLpada}$ kelompok STZ dan $346,42 \pm 50,23 \mathrm{mg} / \mathrm{dL}$ pada kelompok tikus STZ yang diberi Guma Arabic 15\%.Tikus diabetes yang diberi GA 15\% mengalami penurunan kadar glukosa darah secara terus menerus sampai mencapai $96,42 \pm 13,45 \mathrm{mg} / \mathrm{dL}$ dan 82,14 $\pm 9,19 \mathrm{mg} / \mathrm{dL}$. Kesimpulan pada penelitan ini pemberian GA $15 \%$ dapat menurunkan kadar glukosa darah pada tikus diabetes.

Keywords: Diabetes mellitus, Gum Arabic, Blood Glucose Level.

*)Corresponding author:

Hidayat Teguh Wiyono

E-mail: teguh.unej@gmail.com

\section{PENDAHULUAN}

Diabetes mellitus merupakan penyakit gangguan metabolik yang ditandai meningkatnya kadar gula dalam darah diatas normal. Penyakit diabetes terbagi menjadi beberapa tipe, yaitu diabetes mellitus tipe 1, diabetes mellitus tipe 2 dan diabetes gestasional. Diabetes mellitus tipe 1 terjadi karena sistem imun yang menyerang sel $\beta$ pankreas, sehingga tidak dapat menghasilkan insulin [1]. Diabetes mellitus tipe 2 terjadi apabila pankreas masih dapat menghasilkan insulin namun sel- sel tubuh tidak sensitif lagi terhadap insulin sehingga gula dalam darah tidak dapat masuk ke dalam sel yang mengakibatkan kadar gula dalam darah meningkat [2]. Diabetes gestasional merupakan tipe diabetes yang diderita oleh wanita hamil disebabkan meningkatnya kebutuhan energi serta hormon estrogen selama masa kehamilan [3]. Sebagai model penelitian digunakan tikus (Rattus novergicus) yang diinduksi oleh streptozotocin (STZ). STZ merupakan bahan kimia yang digunakan untuk menginduksi diabetes pada hewan coba karena memiliki kemampuan mempertahankan kondisi tubuh dalam keadaan diabetes [4]. STZ memiliki struktur separuh glukosa yang memudahkan untuk berikatan dengan glucose transporter 2 (GLUT2) sehingga dapat masuk ke dalam sel $\beta$ pankreas dan menyebabkan respon hiperglikemik [5]. Kadar gula darah penderita diabetes dapat dikontrol dengan mengkonsumsi obatobatan. Obat antidiabetes kimia dapat menyebabkan efek samping seperti mual, muntah, hipoglikemia, 
pusing, tremor dan konstipasi [6]. Efek samping dari pengobatan secara kimia menyebabkan banyak dilakukan penelitian mengenai pengobatan secara alami untuk mengatur kadar gula darah pada penderita diabetes. Gum arabic mengandung karbohidrat, protein dan mineral serta metabolit sekunder berupa alkaloid, tanin dan saponin. Berdasarkan kandungan yang dimiliki, gum arabic telah banyak dimanfaatkan untuk pengobatan berbagai penyakit, seperti batuk, diare, disentri, dan inflamasi mukosa intestinal [7].

\section{METODE PENELITIAN}

Penelitian ini menggunakan Rancangan Acak Lengkap (RAL). Hewan uji yang digunakan 21 ekor tikus (Rattus novergicus) jantan galur Wistar umur 8-10 minggu dengan berat badan 150-200 gram. Induksi diabetes dilakukan dengan menyuntikkan dosis tunggal streptozotocin sebesar $40 \mathrm{mg} / \mathrm{kg}$ BB lalu diukur kadar gula darah dan apabila kadar gula darah telah mencapai $\geq 126 \mathrm{mg} / \mathrm{dL}$ maka dilanjutkan pemberian larutan gum arabic (Acacia nilotica). Tikus dibagi menjadi 3 kelompok.

Kelompok 1: Tikus tidak diinduksi STZ dan tanpa pemberian larutan gum Arabic 15\%.

Kelompok 2: Tikus diinduksi STZ dan tanpa pemberian larutan gum Arabic 15\%.

Kelompok 3: Tikus diinduksi STZ dan pemberian larutan gum Arabic 15\%.

Kadar gula darah tikus diuji dengan T-Test dan GLM Repeated Measure. T-Test untuk mengetahui beda nyata antara sebelum dan sesudah induksi STZ. GLM Repeated Measure untuk mengetahui pengaruh pemberian GA 15\%.

\section{HASIL DAN PEMBAHASAN}

\section{Pengaruh Pemberian Streptozotocin Terhadap Kadar Gula Darah Tikus}

Tabel 1. Kadar Gula Darah Tikus Pasca Pemberian Streptozotocin

\begin{tabular}{ccc}
\hline \multirow{2}{*}{ Kelompok } & \multicolumn{2}{c}{ Kadar Gula Darah $(\mathrm{mg} / \mathrm{dL})$} \\
\cline { 2 - 3 } & Hari ke-0 $(\overline{\boldsymbol{x}} \pm$ SD $)$ & Hari ke- $7(\overline{\boldsymbol{x}} \pm \mathrm{SD})$ \\
\hline Kontrol & $78,57 \pm 11,90$ & $77,42 \pm 5,38$ \\
STZ & $74,85 \pm 6,86$ & $375 \pm 6,53$ \\
\hline
\end{tabular}

Tabel 1 menunjukkan bahwa rata-rata kadar gula darah sebelum pemberian STZ (hari ke-0) pada kelompok kontrol dan kelompok STZ tidak berbeda nyata yaitu dalam berada dalam kisaran normal

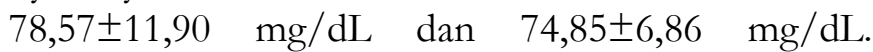
Menurut [8], kadar gula darah tikus dalam rentang normal pada kisaran 63-120,6 mg/dL. Rata-rata kadar gula darah sesudah pemberian STZ pada hari ke-7 menunjukkan perbedaan nyata antara kelompok kontrol dan kelompok STZ. Kelompok STZ mengalami peningkatan kadar gula darah dari $74,85 \pm 6,86 \mathrm{mg} / \mathrm{dL}$ menjadi $375 \pm 6,53 \mathrm{mg} / \mathrm{dL}$ yang menunjukkan bahwa tikus mengalami kondisi diabetes. Sedangkan kelompok kontrol menunjukkan kadar gula darah masih dalam rentang normal yaitu $77,42 \pm 5,38 \mathrm{mg} / \mathrm{dL}$. Kadar gula darah tikus setelah diinjeksi STZ yang melebihi $126 \mathrm{mg} / \mathrm{dL}$ merupakan tanda bahwa tikus telah menderita diabetes [9].

STZ menyebabkan peningkatan sintesis nitric oxide (NO) sehingga terjadi degenerasi sel $\beta$ pankreas [5]. Nitric oxide (NO) termasuk kelompok reactive oxygen species (ROS) yang memberikan efek meningkatnya stres oksidatif sehingga menyebabkan kemampuan pankreas untuk sekresi insulin menurun [10][11]. Menurunnya sekresi insulin menyebabkan kadar gula darah dalam tubuh meningkat dikarenakan sel-sel $\beta$ pankreas mengalami apoptosis [12].

Tikus diabetes akibat induksi STZ menunjukkan gejala glucosuria (glukosa yang terbuang bersama urin) dan diuresis [13]. Glucosuria menekan diuresis osmotik menyebabkan ginjal kehilangan elektrolit sehingga volume urin, dan ekskresi $\mathrm{Na}^{+}, \mathrm{K}^{+}$, serta urea meningkat [14]. Tubuh yang semakin kehilangan elektrolit akan mengalami dehidrasi dan kekurangan cairan ekstraseluler sehingga penderita diabetes cenderung mengalami peningkatan volume minum [13]. Glucosuria yang dialami penderita diabetes menyebabkan tubuh menjadi kehilangan kalori karena glukosa dikeluarkan melalui urin [15]. Glukosa yang tidak dapat diserap oleh tubuh menyebabkan tubuh akan mencari pengganti sumber energi lain sehingga penderita diabetes dapat mengalami kehilangan berat badan drastis dan nafsu makan meningkat [16]. 


\section{Pengaruh Pemberian Gum Arabic Terhadap Kadar Gula Darah Tikus Diabetes}

Tabel 2. Kadar Gula Darah Tikus Diabetes Pasca Pemberian Gum Arabic

\begin{tabular}{ccccc}
\hline \multirow{2}{*}{$\begin{array}{c}\text { Kelomp } \\
\text { ok }\end{array}$} & $\begin{array}{c}\text { Hari ke- } \\
(\overline{\boldsymbol{x}} \pm \text { SD })\end{array}$ & $\begin{array}{c}\text { Hari ke-14 } \\
(\overline{\boldsymbol{x}} \pm \mathrm{SD})\end{array}$ & $\begin{array}{c}\text { Hari ke-21 } \\
(\overline{\boldsymbol{\chi}} \pm \mathrm{SD})\end{array}$ & $\begin{array}{c}\text { Hari ke-28 } \\
(\overline{\boldsymbol{\chi}} \pm \mathrm{SD})\end{array}$ \\
\hline Kontrol & $77,42 \pm 5,38$ & $77 \pm 4,47$ & $74,42 \pm 7,45$ & $78 \pm 8,40$ \\
STZ & $375 \pm 6,53$ & $479,28 \pm 66$, & $479,42 \pm 46$, & $420,28 \pm 63$, \\
& & 01 & 31 & 24 \\
STZ+G & $346,42 \pm 50$, & $479,14 \pm 66$, & $96,42 \pm 13$, & $82,14 \pm 9,19$ \\
A 15\% & 23 & 29 & 45 & \\
\hline
\end{tabular}

Tabel 2 menunjukkan bahwa rata-rata kadar gula darah hari ke-14 pada kelompok diabetes menunjukkan perbedaan tidak nyata dengan kelompok STZ yang diberi gum arabic 15\%. Pada hari ke-14 kadar gula darah tikus STZ dan tikus STZ yang diberi gum arabic 15\% mengalami peningkatan dibandingkan hari ke-7. Kadar gula darah pada dua kelompok tersebut tidak menunjukkan perbedaan yang nyata. Hal ini disebabkan karena gum arabic baru diberikan pada hari ke-14. Pada hari ke-21 terjadi penurunan kadar gula darah pada tikus diabetes yang diberi gum arabic $15 \%$, sedangkan tikus diabetes yang tidak diberi gum arabic 15\% menunjukkan kadar gula darah yang tetap tinggi, meskipun terjadi sedikit penurunan.

Penurunan kadar gula darah pada kelompok tikus yang diberi gum arabic diduga karena gum arabic merupakan non digestable polysakarida. Menurut [7] bakteri usus besar memfermentasi gum arabic secara perlahan sehingga menghasilkan short chain fatty acid (SCFA). Hasil fermentasi berupa SCFA terbagi menjadi acetat (C2), propionate (C3), dan butyrate (C4) [17]. Butyrate menstimulasi peningkatan sekresi hormon glucagon like peptide-1 (GLP-1) oleh sel L sehingga ekspresi GLUT 4 meningkat [18][19]. GLUT 4 berperan sebagai transporter glukosa agar dapat masuk ke dalam sel otot rangka. Ekspresi GLUT 4 meningkat disebabkan GLP-1 mengaktivasi phospoinostide 3-kinase (PI3K) pada sel otot rangka sehingga glukosa yang masuk ke dalam sel otot rangka juga meningkat [20].

Kandungan metabolit sekunder dalam gum arabic seperti alkaloid, tanin dan saponin juga berperan untuk menurunkan kadar gula darah [21]. Alkaloid berpotensi dalam menurunkan kadar gula darah dengan menghambat kerja enzim a-glukosidase yang berperan dalam perombakan glukosa dalam usus [22].
Tanin memiliki potensi dalam menurunkan kondisi hiperglikemia dengan menginduksi regenerasi sel $\beta$ pankreas sehingga produksi insulin menjadi meningkat [23]. Saponin dalam gum arabic berperan dalam menurunkan kadar gula darah dengan menghambat aktivitas enzim a-glukosidase dan meningkatkan produksi insulin yang dihasilkan sel $\beta$ pankreas [24][25].

Grafik perubahan kadar gula darah antar kelompok dengan analisis uji General Linear Model (GLM) Repeated Measure dapat dilihat pada Gambar 1. Berdasarkan hasil tersebut tampak bahwa kadar gula darah setelah pemberian gum arabic menunjukkan penurunan yang sangat tajam.

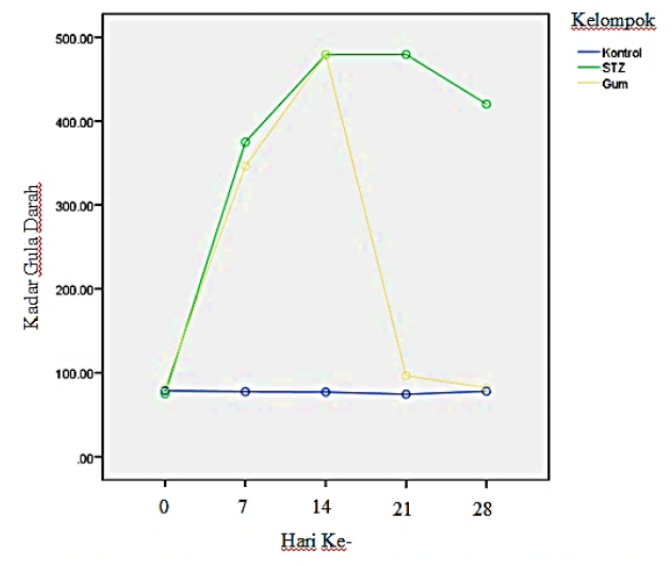

Gambar 1. Grafik perubahan kadar gula darah tikus antara kelompok kontrol, STZ dan STZ+GA $15 \%$

Gambar 1 menunjukkan bahwa kadar gula darah kelompok gum arabic 15\% pada hari ke-14 hingga ke28 mengalami penurunan yang signifikan dibanding kelompok diabetes. Efek pemberian gum arabic pada hewan uji yang menderita diabetes menunjukkan berkurangnya glukosa pada urin (glucosuria) [26]. Gum arabic berperan dalam meningkatkan kadar $\mathrm{ADH}$ sehingga menyebabkan berkurangnya volume urin dan ekskresi $\mathrm{Na}^{+}, \mathrm{K}^{+}$, serta urea [27]. Butyrate yang meningkat dikarenakan fermentasi gum arabic oleh bakteri usus besar membantu meningkatkan pada ginjal sehingga kadar ADH juga meningkat [26]. Mencit diabetes yang diberi perlakuan gum arabic 15\% menunjukkan penurunan aktivitas sodium glucose transporter1 (SGLT1) sehingga penyerapan makronutrien dilakukan secara perlahan oleh tubuh. Efek dari menurunnya aktivitas SGLT1 juga menyebabkan berkurangnya sekresi hormon leptin 
sehingga mengurangi rasa lapar [28][29]. Hormon leptin yang dihasilkan oleh jaringan lemak berfungsi untuk menghambat rasa lapar dan meningkatkan metabolisme energi [30]. Berdasarkan hasil penelitian diketahui bahwa tikus diabetes yang diberi gum arabic dosis 15\% sebanyak 3 kali seminggu selama 6 minggu menunjukkan penurunan kadar gula darah dari $361,806 \mathrm{mg} / \mathrm{dL}$ menjadi $140 \mathrm{mg} / \mathrm{d}$ [31].

\section{KESIMPULAN}

Berdasarkan penelitian yang telah dilakukan, pemberian gum arabic 15\% menurunkan kadar gula darah tikus (Rattus novergicus) diabetes.

\section{DAFTAR PUSTAKA}

[1] P. Champe, R. Harvey, and D. Ferrier, Biokimia Edisi 3. Jakarta: Penerbit Buku Kedokteran EGC, 2010.

[2] N. Putri, and M. Isfandiari, "Hubungan empat pilar pengendalian $\mathrm{dm}$ tipe 2 dengan rerata kadar gula darah," J. Epidemilogi Berkala., vol. 1, no. 2, 2013.

[3] J. Corwin, Buku Saku Patofisiologi Edisi 3. Jakarta: Penerbit Buku Kedokteran EGC, 2009.

[4] C. Eleazu, K. Eleazu, S. Chukwuma, and U. Essien, "Review of the mechanism of cell death resulting from streptozotocin challenge in experimental animals, its practical use and potential risk," J. Diabetes and Metabolic Disorders, vol. 12, no. 1, pp. 1-7, 2013.

[5] T. Szkudelski, "The mechanism of alloxan and streptozotocin action in b cells of the rat pancreas," $J$. Physiological Research, vol. 50, pp. 537-546, 2001.

[6] R. Putra, A. Achmad, and H. Rachma, "Kejadian efek samping potensial terapi obat anti diabetes pasien diabetes mellitus berdasarkan algoritma naranjo," $J$. Pharmaceutical Journal of Indonesia, vol. 2, no. 2, pp. 4550, 2017.

[7] M. Montenegro, Boiero, L. Valle, and C. Borsarelli, Gum Arabic: More than an edible emulsifier. In C. J. R. Verbeek (Ed.) Products and applications of biopolymers. Croatia: Intech, 2012.

[8] W. Kerner, and J. Brückel, "Definition, classification and diagnosis of diabetes mellitus," J. Experimental and Clinical Endocrinology, vol. 122, no. 7, pp. 384-386, 2014.

[9] C. Talubmook, "Effect of polysaccharide from Phellinus igniarius (L.) Quel. on hematological values and blood cell characteristics in diabetic rats," J. Microscop Social Thailand, vol. 22, pp. 42-45, 2008.

[10] H. Lai, "Antioxidant effects and insulin resistance improvement of chromium combined with vitamin $C$ and E supplementation for type 2 diabetes mellitus," $J$.
Clinical Biochemistry Nutrition, vol. 43-44, pp. 191-8, 2008.

[11] K. Hamden, B. Jaouadi, S. Carreau, A. Aouidet, and A. Elfeki, "Therapeutic effects of soy isoflavones on $\alpha$ amylase activity, insulin deficiency, liver- kidney function and metabolic disorders in diabetic rats," $J$. Natural Product Research, vol. 25, no. 3, pp. 244-55, 2011.

[12] A. Husni, D. Purwanti, and Ustadi, "Blood glucose level and lipid profile of streptozotocin-induced diabetes rats treated with sodium alginate from Sargassum crassifolium," J. Biological Sciences, vol. 16, no. 3, pp. 58-64, 2016.

[13] R. Hebden, S. Gardiner, T. Bennet, and I. MacDonald, "The influence of streptozotocin-induced diabetes mellitus on fluid and electrolyte handling in rats," $J$. Clinical Science, vol. 70, pp. 111-117, 1986.

[14] I. Lang, "Osmotic diuresis," J. Renal Physiology, vol. 10, pp. 160-173, 1987.

[15] D. Granner, Hormones of the Pancreas and Gastrointestinal Tract, Connecticut: Appleton and Lange, 1996.

[16] U. Okon, D. Owo, N. Udokang, J. Udobang, and C. Ekpenyong, "Oral administration of aqueous leaf extract of Ocimum gratissimum ameliorates polyphagia, polydipsia and weight loss in streptozotocin- induced diabetic rats," J. Medicine and Medical Sciences, vol. 2, no. 3, pp. 45-49, 2012.

[17] S. Cook, and J. Sellin, "Review article: short chain fatty acids in health and disease," J. Alimentary pharmacology \& Therapentics, vol. 12, no. 6, pp. 499-507, 1998.

[18] G. Besten, K. Eunen, A. Groen, K. Venema, D. Reijngoud, and B. Bakker, "The role of short-chain fatty acids in the interplay between diet, gut microbiota, and host energy metabolism," J. Lipid Research, vol. 54, pp. 2325-2340, 2013.

[19] M. Peñacarrillo, J. Puente, A. Redondo, F. Clemente, and I. Valverde, "Effect of GLP-1 treatment on GLUT2 and GLUT4 expression in type 1 and type 2 rat diabetic models," J. Endocrine, vol. 15, no. 1, pp. 241 248, 2001.

[20] C. Green, T. Henriksen, B. Pedersen, and T. Solomon, "Glucagon like peptide-1-induced glucose metabolism in differentiated human muscle satellite cells is attenuated by hyperglycemia," J. PloS ONE, vol. 7, no. 8, pp. 1-11, 2012.

[21] K. Ali, T. Salih, and H. Daffalla, "In vitro phytochemical, larvicidal and antimicrobial activities of gum arabic extract," J. Walailak Science and Tecbnology, vol. 17, no. 3, pp. 192-199, 2020.

[22] J. Kawabata, K. Mizhuhata, E. Sato, T. Nishioka, Y. Aoyama, and T. Kasai, "6- Hydroxyflavonoids as $\alpha$ glucosidase inhibitor from marjoram (Origanum marjorana) leaves," J. Biosci. Biotechno. Biochem., vol. 67, pp. 445-447, 2003. 
[23] M. Kumari, and S. Jain, "Tannins : an antinutrient with positive effect to manage diabetes," J. Recent Science, vol. 1, no. 12, pp. 70-1, 2012.

[24] N. Metwally, A. Mohammed, and F. Elsharabasy, "Chemical constituents of the egyptian plant Anabasis articulate (Forssk) moq and its antidiabetic effects on rats with streptozotocin-induced diabetic hepatopathy," J. Applied Pharmaceutical Science, vol. 2, no. 4, pp. 54-65, 2012.

[25] K. Lee, T. Jung, H. Lee, S. Kim, Y. Shin, and W. Whang, "The antidiabetic effect of ginsenoside $\mathrm{Rb} 2$ via activation of AMPK," J. Archives of pharmacal research, vol. 34, no. 7, pp. 1201-1208, 2011.

[26] O. Nasir, A. Umbach, R. Rexhepaj, T. Ackermann, M. Bhandaru, A. Ebrahim, F. Artunc, D. Kempe, G. Puchchakayala, B. Siraskar, M. Föller, A. Saeed, and F. Lang, "Effects of gum arabic (Acacia senegal) on renal function in diabetic mice," J. Kidney Blood Pressure Research, vol. 35, pp. 365-372, 2012.

[27] O. Nasir, F. Artunc, A. Saeed, M. Kambal, H. Kalbacher, D. Sandulache, K. Boini, N. Jahovic, and F. Lang, "Effects of gum arabic (Acacia senegal) on water and electrolyte balance in healthy mice," J. Renal Nutrition, vol. 18, pp. 230-238, 2008.

[28] O. Nasir, F. Artune, K. Wang, R. Rexhepaj, M. Föller, and A. Ebrahim, "Downregulation of mouse intestinal $\mathrm{Na}$-coupled glucose transporter SGLT1 by gum arabic (Acacia senegal)," J. Cell Physiology Biochemistry, vol. 25, no. 2-3, pp. 203-10, 2010.

[29] R. Mattes, and D. Rothacker, "Beverage viscosity is inversely related to postprandial hunger in humans," $J$. Physiology Behavior, vol. 74, no. 4-5, pp. 551-7, 2001.\

[30] A. Cahayaningrum, "Leptin sebagai indikator obesitas," J. Kesehatan Prima, vol.9, no. 1, pp. 1364-1371, 2015.

[31] E. Tobgy, "Protective role of gum arabic (Acacia senegal) on oxidative stress in diabetic and adenineinduced chronic renal failure in rats," J. ChenTech Research, vol. 12, no. 1, pp. 223-234, 2019. 